Article

\title{
Visible Light-Responsive Platinum-Containing Titania Nanoparticle-Mediated Photocatalysis Induces Nucleotide Insertion, Deletion and Substitution Mutations
}

\author{
Der-Shan Sun ${ }^{1,2}$, Yao-Hsuan Tseng ${ }^{3}$, Wen-Shiang Wu ${ }^{1}$, Ming-Show Wong ${ }^{4}$ and \\ Hsin-Hou Chang 1,2,* \\ 1 Department of Molecular Biology and Human Genetics, Tzu-Chi University, Hualien 97004, Taiwan; \\ dssun@mail.tcu.edu.tw (D.-S.S.); englishbiology@yahoo.com.tw (W.-S.W.) \\ 2 Nanobiomedical Research Center, Tzu-Chi University, Hualien 97004, Taiwan \\ 3 Department of Chemical Engineering, National Taiwan University of Science and Technology, Taipei 10607, \\ Taiwan; tyh@mail.ntust.edu.tw \\ 4 Department of Materials Science and Engineering, National Dong-Hwa University, Hualien 97401, Taiwan; \\ mswong@mail.ndhu.edu.tw \\ * Correspondence: hhchang@mail.tcu.edu.tw; Tel.: +886-3-8565301 (ext. 2667)
}

Academic Editor: Guogang Ren

Received: 14 October 2016; Accepted: 22 December 2016; Published: 28 December 2016

\begin{abstract}
Conventional photocatalysts are primarily stimulated using ultraviolet (UV) light to elicit reactive oxygen species and have wide applications in environmental and energy fields, including self-cleaning surfaces and sterilization. Because UV illumination is hazardous to humans, visible light-responsive photocatalysts (VLRPs) were discovered and are now applied to increase photocatalysis. However, fundamental questions regarding the ability of VLRPs to trigger DNA mutations and the mutation types it elicits remain elusive. Here, through plasmid transformation and $\beta$-galactosidase $\alpha$-complementation analyses, we observed that visible light-responsive platinum-containing titania $\left(\mathrm{TiO}_{2}\right)$ nanoparticle (NP)-mediated photocatalysis considerably reduces the number of Escherichia coli transformants. This suggests that such photocatalytic reactions cause DNA damage. DNA sequencing results demonstrated that the DNA damage comprises three mutation types, namely nucleotide insertion, deletion and substitution; this is the first study to report the types of mutations occurring after photocatalysis by $\mathrm{TiO}_{2}-\mathrm{VLRPs}$. Our results may facilitate the development and appropriate use of new-generation $\mathrm{TiO}_{2} \mathrm{NPs}$ for biomedical applications.
\end{abstract}

Keywords: visible light-responsive photocatalyst; $\mathrm{TiO}_{2} ;$ nanoparticle; DNA mutation; lacZ $\alpha$-complementation

\section{Introduction}

Antibacterial agents, such as antibiotics and disinfectants, are crucial for personal hygiene, water treatment and food production and in healthcare facilities to control the spread of infectious diseases. The overuse of antibiotics and the emergence of antibiotic-resistant and virulent microbial strains has necessitated the urgent development of alternative sterilization technologies. Despite several advancements in antibiotics research, antibiotic-resistant bacterial infections have become a major clinical challenge worldwide because the frequency of outbreaks and epidemics remains high [1].

Photocatalysts are potentially useful in various settings for reducing pathogen transmission in public environments. Titanium dioxide or titania $\left(\mathrm{TiO}_{2}\right)$ substrates, which are primarily induced using ultraviolet (UV) light, are the most frequently-used photocatalysts for antibacterial applications [2-4]. The photon energy excites electrons from the valence band to the conduction band, generating positive 
holes (electron vacancy) in the valence band. The excited electrons and holes are trapped on the $\mathrm{TiO}_{2}$ surfaces. These electrons and holes may then recombine and release energy as light or heat, resulting in inefficient photocatalysis. Alternatively, they may react with atmospheric water and oxygen to yield a reactive oxygen species (ROS), such as hydrogen peroxide, hydroxyl radicals $(\cdot \mathrm{OH})$ or superoxide anions $\left(\mathrm{O}_{2}^{-}\right)$[5]. These $\mathrm{ROS}$ are powerful biocides that eliminate pathogenic microorganisms. However, human exposure to UV light at bactericidal levels can considerably damage skin and eye tissues [6,7], which limits the use of conventional UV light-induced $\mathrm{TiO}_{2}$ substrates in environments where human exposure may occur. This problem can be resolved by impurity doping $\mathrm{TiO}_{2}$ with different elements, such as carbon, sulfur, nitrogen and silver, which shifts the excitation wavelength from the UV region to the visible light region [2,8-19]. Simultaneously, this process may also reduce the recombination rates of the electron and hole pairs. Visible light-responsive antibacterial photocatalysts (which have a higher quantum efficiency under sunlight than do UV light-responsive photocatalysts) can be safely used in indoor settings to prevent human exposure to UV light [2,8-11,13-16].

The molecular targets of photocatalysis in bacteria (e.g., DNA, RNA, protein and cell membrane) and the intensity at which these are affected remain unclear. Because photocatalytic reactions involve both oxidation and reduction [20,21], damage observed in the target microorganisms differs from that observed with traditional disinfectants, which involve either oxidation or reduction. This is probably the reason that we previously observed a unique pattern of photocatalysis-induced bacterial destruction $[2,10]$. UV light-responsive $\mathrm{TiO}_{2}$ induces DNA damage without specified temperature control [22,23]; however, UV light alone can also induce DNA mutation and damage [24,25]. In addition, photocatalysis at room temperature $\left(25^{\circ} \mathrm{C}\right)$ induces more DNA damage than that $4{ }^{\circ} \mathrm{C}$ (Figure 1). The absorption of illuminated light energy can produce heat; thus, illumination-induced heat also potentially has a major role in triggering DNA damage. However, visible light-responsive photocatalyst (VLRP)-induced DNA mutations have not been clearly characterized thus far. Therefore, the exact photocatalysis-induced DNA damage, without perturbations of the effects of heat and UV light, warrants further investigation. In the present study, we used a previously-reported visible light-responsive platinum-containing titania $\left(\mathrm{TiO}_{2}-\mathrm{Pt}\right)$ photocatalytic nanoparticle $(\mathrm{NP})[11,16]$ to address this question. Our data revealed that VLRPs can induce DNA mutations.

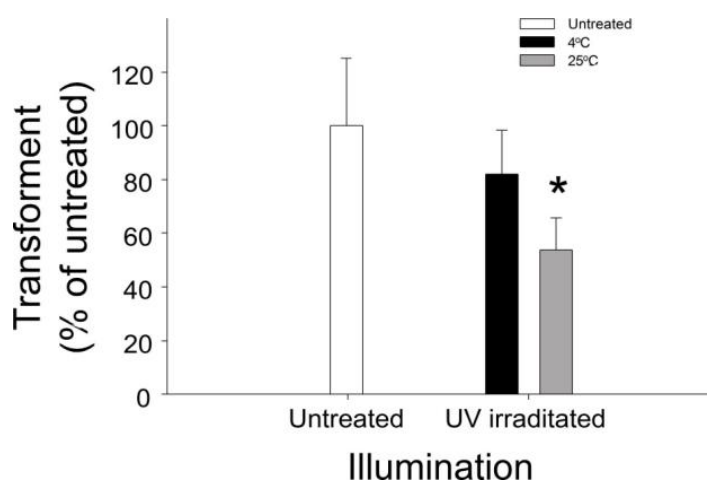

Figure 1. Influence of heat on photocatalyst-induced DNA damage. Plasmid pBlueScript II SK ${ }^{+}$DNA was transformed to Escherichia coli (E. coli) competent cells after photocatalysis environments set to $4{ }^{\circ} \mathrm{C}$ and $25^{\circ} \mathrm{C}$. The level of DNA damage involving ultraviolet (UV)- and heat-induced nanoscale- $\mathrm{TiO}_{2}$ film-mediated photocatalysis was indicated by the reduction of transformants. ${ }^{*} p<0.05$ vs. $4{ }^{\circ} \mathrm{C}$ group. $n=6$, three experiments with two replicates.

\section{Results}

\subsection{Involvement of Heat in VLRP-Induced Plasmid DNA Damage}

Photocatalysts can absorb light energy and produce heat [26]; simultaneously, heat can also induce ROS production and DNA damage [27]. Herein, we observed that the temperature of photocatalytic 
films under UV irradiation rapidly increased, easily reaching more than $200^{\circ} \mathrm{C}$. To investigate whether temperature is involved in photocatalytic DNA damage, we used UV-irradiated single-layer $\mathrm{TiO}_{2}$ thin films [13] to catalyze plasmid DNA (pBlueScript II SK ${ }^{+}$) in environments at $25{ }^{\circ} \mathrm{C}$ and $4{ }^{\circ} \mathrm{C}$. After transforming the photocatalyzed plasmid DNA into competent Escherichia coli (E. coli) cells, we observed that the experimental samples catalyzed at $4{ }^{\circ} \mathrm{C}$ contained considerably more transformants than did those catalyzed at $25^{\circ} \mathrm{C}$ (Figure 1). These results suggest that illumination-induced heat also plays a major role in inducing DNA damage.

\subsection{VLRP Induces Plasmid DNA Damage}

Both UV light and heat contributed to the DNA damage noted herein; thus, to analyze the DNA damage specifically induced through photocatalysis, we performed a photocatalysis of plasmid DNA using visible light-responsive $\mathrm{TiO}_{2}-\mathrm{Pt} \mathrm{NPs}$ as compared to UV-responsive pure-anatase $\mathrm{TiO}_{2} \mathrm{NPs}$ at $4{ }^{\circ} \mathrm{C}$ for $1 \mathrm{~h}$. The results revealed that the number of $E$. coli transformants considerably decreased with the increase in visible light illumination intensity (Figure $2 \mathrm{~A} ; \mathrm{TiO}_{2}-\mathrm{Pt}$ groups), indicating that the DNA damage is induced in a dose-dependent manner. Because light intensity of $10^{4}$ lux is an effective dose to reduce the E. coli transformants (Figure 2A), we used that as the constant illumination intensity with increasing illumination time to obtain a kinetic result. Here, we noted a decrease in the number of transformants, associated with the increasing illumination time (Figure 2B). The DNA samples of those dark groups were covered with aluminum foil to prevent photocatalysis, and thus, no particular response occurred. Because the pure anatase $\mathrm{TiO}_{2} \mathrm{NPs}$ are UV-responsive, it is reasonable that no DNA damage was observed in the " $\mathrm{TiO}_{2}$ light" groups (Figure 2A,B). These results confirm that VLRPs can elicit DNA damage.
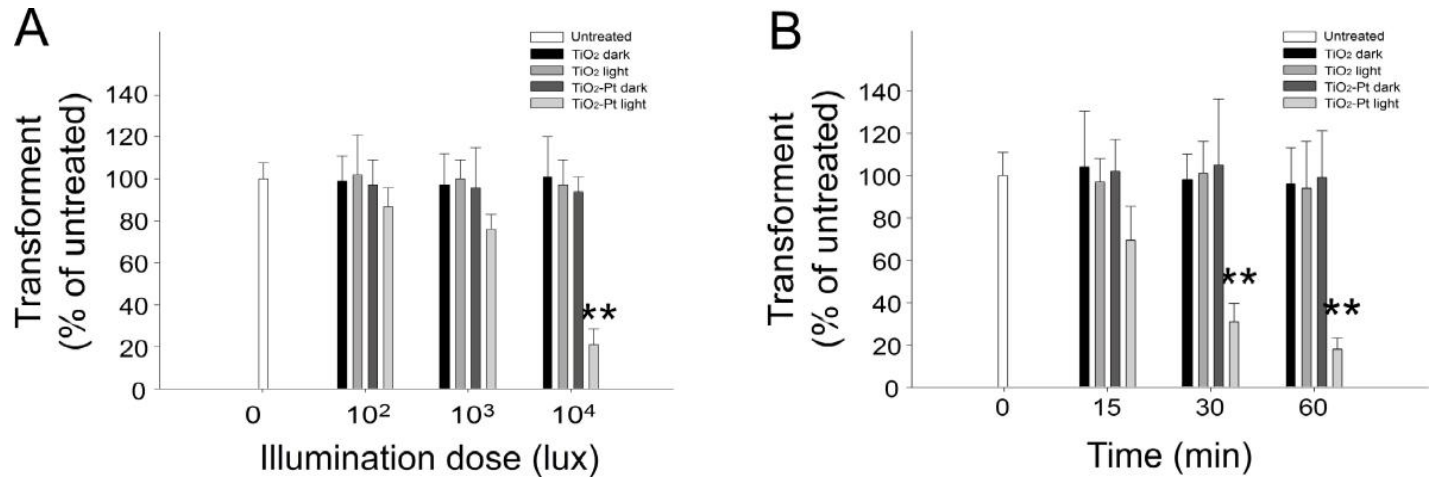

Figure 2. (A) Dose-dependent and (B) kinetic responses, with increasing illumination density and with increasing time, respectively. The visible light stimulated $\mathrm{TiO}_{2}-\mathrm{Pt}$ photocatalysis-mediated DNA damage was determined by the reduction of transformants. The DNA samples of those dark groups were covered with aluminum foil to prevent the photocatalysis. UV-responsive $\mathrm{TiO}_{2} \mathrm{NPs}$ were used as control materials. ${ }^{* *} p<0.01$ vs. respective $\mathrm{TiO}_{2}-\mathrm{Pt}$ dark groups. $n=6$, three experiments with two replicates.

\subsection{Application of VLRP-Induced DNA to Different Plasmids}

We subsequently investigated whether our noted visible light-responsive $\mathrm{TiO}_{2}-\mathrm{Pt} \mathrm{NP}$-mediated photocatalysis-induced DNA damage is also applicable to different plasmids. We employed two additional plasmids, pGEM-2KS and pET21, which are used primarily in bacterial recombinant protein expression [28-38], and observed that VLRPs induced considerable damage in all three plasmids, including the pBlueScript II SK ${ }^{+}$(Figure 3). 


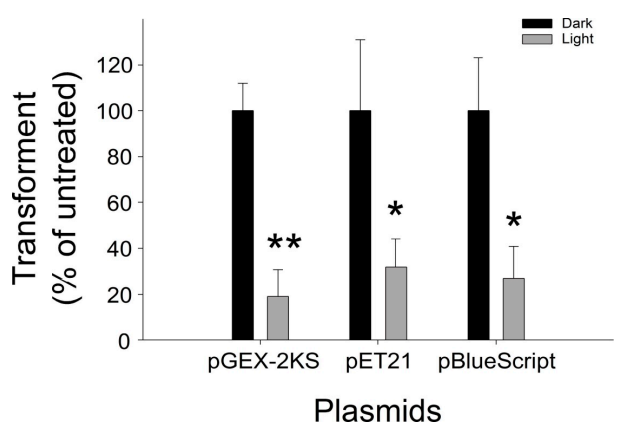

Figure 3. Significant visible light stimulated $\mathrm{TiO}_{2}-\mathrm{Pt}$-mediated photocatalysis-induced DNA damage occurred in the pGEX-2KS, pET16 and pBlueScript II SK ${ }^{+}$plasmids. Notably, these plasmids all displayed similar reductions after the photocatalysis. ${ }^{* *} p<0.01 ;{ }^{*} p<0.05$ vs. respective dark groups. $n=6$, three experiments with two replicates.

\subsection{VLRP Induces Mutations in Plasmid DNA}

To further investigate whether photocatalysis induces mutated DNA damage, we performed an $\alpha$-complementation analysis of the $\beta$-galactosidase gene lac $\mathrm{Z}$ using pBlueScript II $\mathrm{SK}^{+}$and E. coli XL1-blue (Figure S1). Notably, E. coli XL1-blue cells with wild-type plasmids expressed functional $\alpha$-peptide, which complements the defective lac $Z$ to produce blue colonies in the presence of the chromogenic substrate 5-bromo-4-chloro-3-indolyl- $\beta$-D-galactopyranoside (X-gal) (Figure 4A,B). By contrast, the mutant transformant cells containing damaged DNA in the lac $Z \alpha$ region did not produce blue colonies and instead remained white. Thus, using this method, we can differentiate lacZ $\alpha$ mutation-type (white) and wild-type (blue) clones. Even at an extremely low frequency (14/2000; $0.7 \%$ ), visible light-responsive $\mathrm{TiO}_{2}-\mathrm{Pt} \mathrm{NP}$-mediated photocatalysis can induce white colony formation (Figure 4C), indicating that mutations were generated in the lac $\mathrm{Z} \alpha$ region.

A

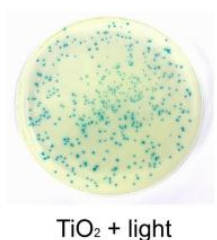

B
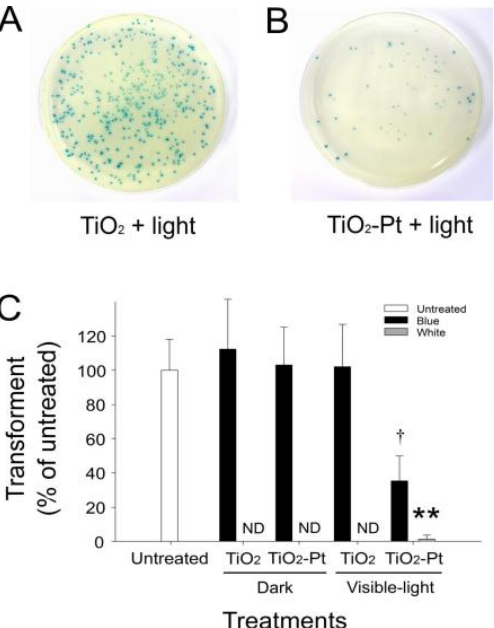

Figure 4. Detection of mutated clones using lacZ $\alpha$-peptide complementation. (A,B) After being complemented with lac $Z \alpha$-peptide expression, the transformants are displayed as blue colonies on the agar plates with 5-bromo-4-chloro-3-indolyl- $\beta$-D-galactopyranoside. The VLRP $\mathrm{TiO}_{2}-\mathrm{Pt} \mathrm{NP}$-mediated photocatalysis markedly reduces the number of transformants, compared with the control groups using UV-responsive $\mathrm{TiO}_{2} \mathrm{NPs}$, under visible light illumination. (C) Quantified results show that $\mathrm{TiO}_{2}-\mathrm{Pt}$ photocatalysis can induce the formation of white colonies. This indicates that mutations hit the $l a c Z \alpha$ region because of a loss-of-function (loss-of-complementation) phenotype, compared with the wild-type plasmid-transformed blue colonies. ND: no detected colony. ${ }^{*} p<0.05$ vs. both blue groups of $\mathrm{TiO}_{2}$-visible light and $\mathrm{TiO}_{2}$-Pt-dark; ${ }^{* *} p<0.01$ vs. respective blue groups. $n=6$, three experiments with two replicates. 


\subsection{VLRP-Induced DNA Mutations Involve Nucleotide Deletion and Substitution}

To further analyze how these mutations were introduced in the plasmid DNA, the lacZ $\alpha$ locus on plasmid DNA in the white colony cells was sequenced, and the mutation types and loci were identified. Because of the long sequence deletion, the $l a c Z \alpha$ region in three clones is likely entirely deleted in 14 isolated white colonies. The remaining 11 colonies contain two clones with identical DNA sequences. Therefore, we analyzed the 10 mutated lacZ $\alpha$ DNA sequences. We observed that the mutations included nucleotide deletions and substitutions (Figure 5; Figure S2 with background color), both of which primarily triggered frameshift mutations leading to a loss-of-function phenotype (white colonies) of the $\alpha$-complementation of $l a c Z$, as indicated in the comparison of parental wild-type $\alpha$-peptide amino acid with the mutant clones (Figure 6). Without exception, all of these mutated plasmids expressed a truncated form of encoded protein (Figure 6).
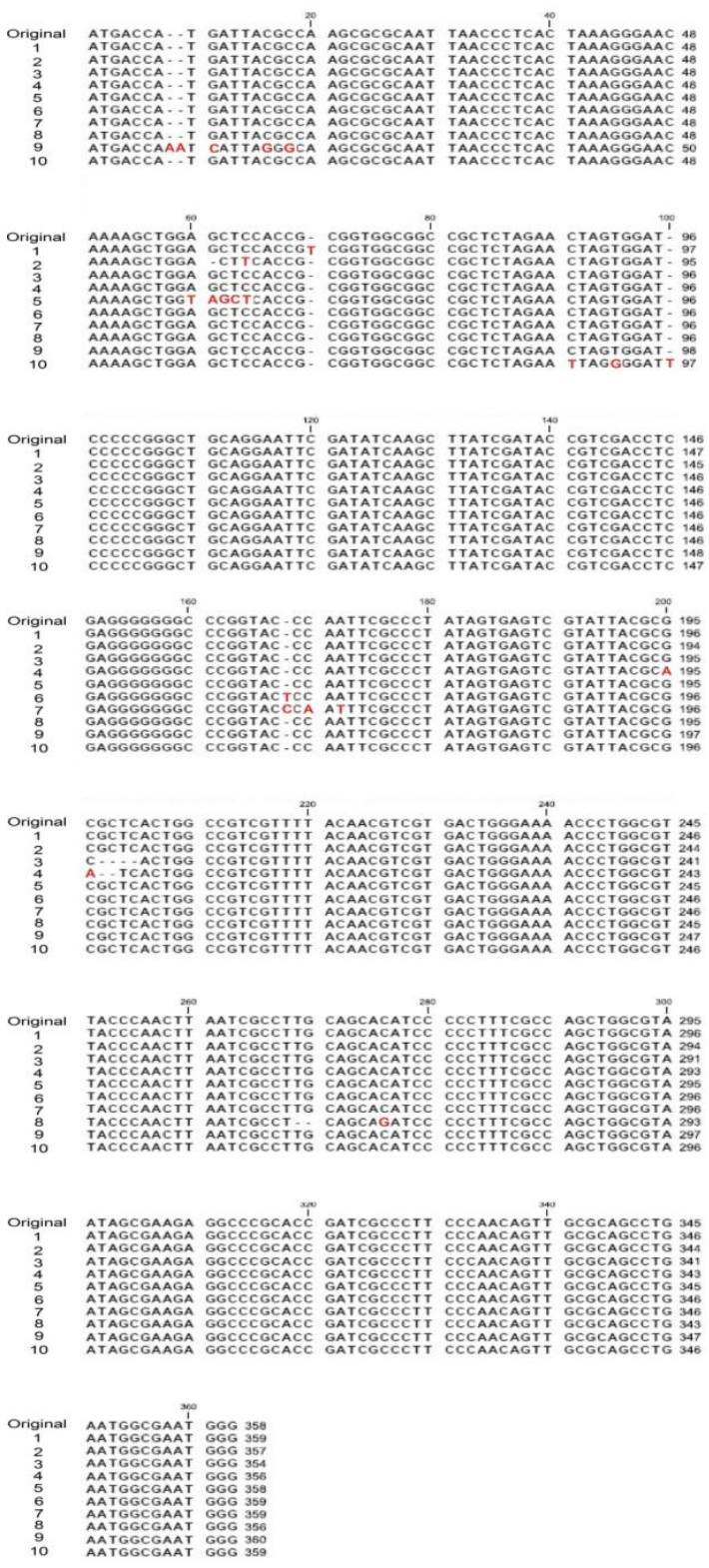

Figure 5. Mutation sites in the lac $Z \alpha$-peptide coding $(\operatorname{lac} Z \alpha)$ region. Examples of DNA sequences in the $l a c Z \alpha$ region of the white colonies are provided, in which insertion (Clones 1, 6, 7, 9 and 10) deletion (Clones 2-4, 8) and nucleotide substitution (Clones 2, 4, 5, 7, 8 and 10) mutation types are involved. The nucleotides at the mutation sites are labeled in red. 

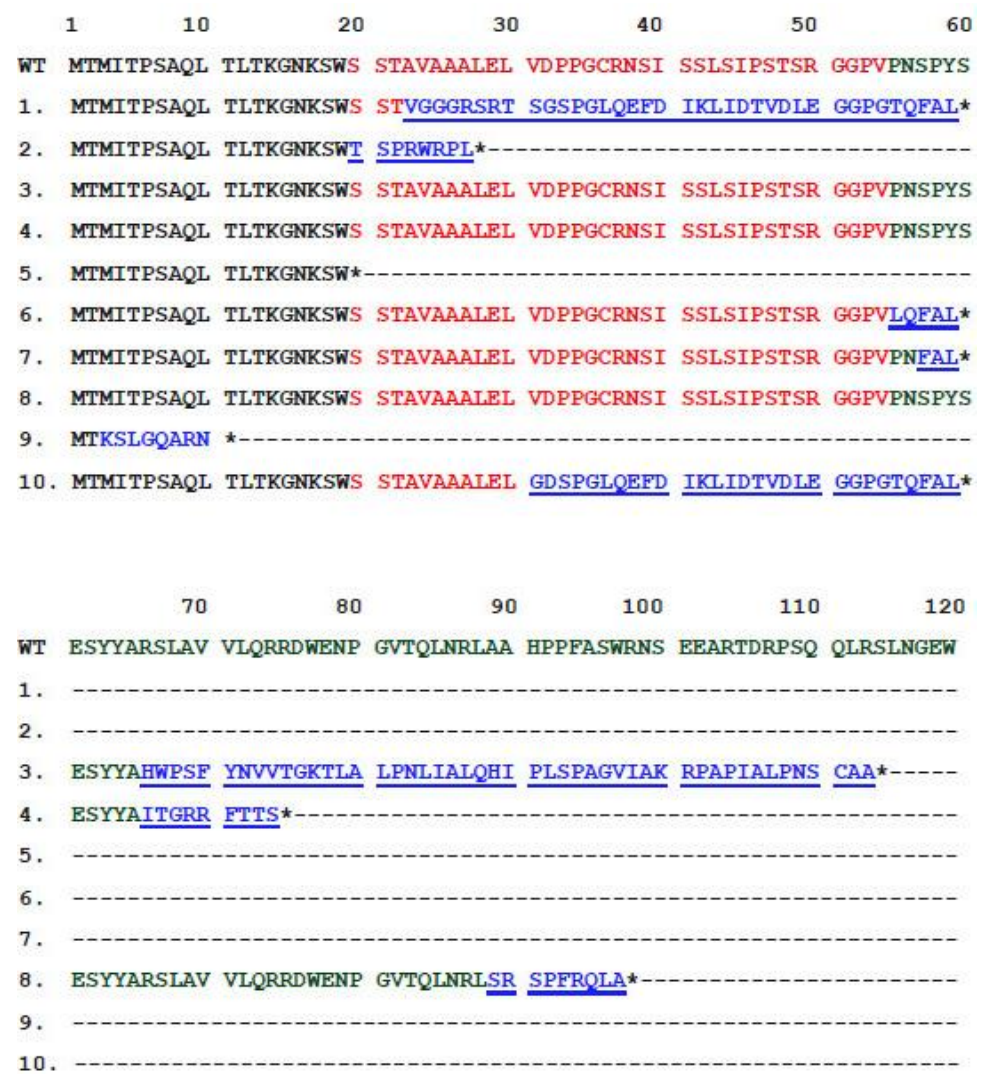

Figure 6. lac $\mathrm{Z} \alpha$-peptide amino acid sequence aliment of one wild-type and 10 mutated clones. The amino acid sequences encoded by multiple cloning sites are labeled in red; the sequences encoded by $l a c Z \alpha$ are labeled in green; and the mutation-caused reading frame shifts are labeled in blue. The * indicates the translation termination by the stop codon.

\section{Discussion}

VLRP-induced DNA mutations have rarely been reported. One study suggested that treatment with $\mathrm{TiO}_{2} \mathrm{NPs}$ alone (i.e., without light-stimulated photocatalysis) can sufficiently induce mutations in plasmid DNA [39]. By contrast, our data indicate that treatments with both $\mathrm{TiO}_{2}$ and $\mathrm{TiO}_{2}-\mathrm{Pt}$ NPs are insufficient to induce DNA damage in darkness (Figure 4), which corroborate several previous reports that $\mathrm{TiO}_{2}$ NPs alone cannot damage plasmid DNA in darkness unless photocatalysis is applied [22,23]. Notably, however, the data in these studies were obtained using experimental conditions without temperature control [22,23]. According to our temperature-controlled experiments (Figure 1), such DNA damage can also be attributed to illumination-induced heat. In addition, the aforementioned studies did not examine the mutation types nor locations [22,23]; therefore, the fundamental question regarding the effects of $\mathrm{TiO}_{2} \mathrm{NP}$-mediated photocatalysis on the induction of DNA mutations remained elusive.

Our data revealed that treatment with $\mathrm{TiO}_{2}-\mathrm{Pt} \mathrm{NP}$ alone is insufficient to induce DNA damage in darkness and that the detectable mutations (i.e., white colonies) can be obtained at an extremely low rate even after VLRP (Figure 4). Some silent mutations, which do not significantly alter the organism phenotype, were also noted outside the lac $\mathrm{Z} \alpha$ region (data not shown), suggesting that photocatalysis randomly hits different regions of the plasmid. Theoretically, photocatalysis can also introduce mutations and damage into vital regions of the plasmid DNA, such as the replication origin and ampicillin resistance gene loci; therefore, photocatalysis can reduce the transformation rate of a plasmid (Figures 2 and 3). 
Here, we observed that the VLRP-induced DNA mutations primarily generated reading frameshifts in all of the mutant clones, except Clone 5 (Figure 5; Figures S1 and S2). Most of these frameshift mutations were caused by photocatalysis-induced insertions and deletions in the plasmid DNA (Figure 5). Because gene expression and protein translation occurs through triplet codons, nucleotide insertion or deletion can shift the reading frame, resulting in the translation of a protein sequence completely different from the original. In addition, frameshift mutations can also introduce an early stop codon (TAA, TGA or TAG). Thus, the translated protein may become abnormally short or long and most likely lose its function. Here, Clone 5 is of particular interest, because the stop codon TAG was directly created at the mutation site, which resulted in the expression of a truncated lacZ $\alpha$-peptide (Figure 6). Consequently, after photocatalysis, a loss-of-function phenotype of these plasmids was noted in the $\alpha$-complementation analysis.

The chemistry of DNA damage caused by ROS has been well characterized in vitro; for instance, $\cdot \mathrm{OH}$ generates multiple products from all four DNA bases [40,41]. ROS-related DNA oxidation is a major cause of mutations, and it can produce several types of damage, including nonbulky (8-oxoguanine and formamidopyrimidine) and bulky (cyclopurine and etheno adducts) base modifications, abasic sites, nonconventional single-strand breaks, protein-DNA adducts and intrastrand or interstrand DNA crosslinks [42-45]. In addition, UV light is high-energy electromagnetic radiation that breaks the backbone or cross-link bases (e.g., thymine dimers and pyrimidine dimers: TT or TC) [46,47]. VLRP can also elicit ROS (such as $\cdot \mathrm{OH}$ and $\mathrm{O}_{2}{ }^{-}$) [5], and even heat can induce the production of ROS, 8-oxoguanine and DNA damage [27]. Therefore, to exclude UV light- and heat-induced DNA damage, we performed photocatalysis using visible light in a temperature-controlled environment. Because the DNA damage was introduced in vitro in our experimental system, the mutation processes of damaged DNA occur in living bacterial cells. DNA damage leads to mutations through three primary pathways: reducing incorporation fidelity, blocking DNA replication and forming frameshifts [48]. UV-responsive $\mathrm{TiO}_{2}$-mediated photocatalysis has been demonstrated to trigger DNA double-strand breaks [22,23,49].

Two distinct mechanisms are involved in double-stranded break repair: homologous recombination and nonhomologous end-joining, and both pathways can introduce mutations into DNA [50,51]. Thymine dimers interfere with base pairing during DNA replication, which leads to mutations; thus, translesion DNA synthesis frequently introduces mutations at pyrimidine dimers, both in prokaryotes and in eukaryotes [52]. The $\mathrm{C}$ involved in pyrimidine dimers is prone to be deaminated, inducing a $C$ to $T$ transition [53]. As a result, all of the aforementioned mechanisms can potentially cause nucleotide insertions, deletions and substitutions in DNA after exposure to ROS [42,43]; this is likely the reason that we observed such damage in our experiments.

In summary, we investigated the DNA mutations caused by visible light-stimulated photocatalysis at $4{ }^{\circ} \mathrm{C}$, without UV irradiation and heat generation. The results revealed that the photolytic response produced plasmid DNA mutation. As per the loss-of-function phenotype observed in the $\alpha$-complementation analysis, the mutation types involved nucleotide insertions, deletions and substitutions, which primarily triggered reading frameshifts and the expression of a malfunctioning $\alpha$-peptide. These results collectively offer novel concepts regarding the safety and potential applications of photocatalytic $\mathrm{TiO}_{2}$ materials. For example, because $\mathrm{TiO}_{2}$ photocatalysis-mediated DNA damage may cause genotoxicity, caution should be exercised during the synthesis, release and use of photocatalytic $\mathrm{TiO}_{2}$ NPs to reduce the environmental impact. By contrast, a DNA damage agent is synergistic with other antibacterial agents, which block different physiological pathways to eliminate pathogenic bacteria [54,55]. Therefore, the genotoxicity of $\mathrm{TiO}_{2}$ photocatalysis may facilitate the development of novel antibacterial strategies to manage the spread of pathogens. In short, our research illuminates fundamental knowledge about $\mathrm{TiO}_{2}-\mathrm{NP}$ photocatalysis-mediated DNA mutations and damage, which may be useful for future studies on environmental safety and new-generation $\mathrm{TiO}_{2}-\mathrm{NP}$ development for biomedical applications. 


\section{Materials and Methods}

\subsection{Photocatalyst Preparation}

UV light-responsive $\mathrm{TiO}_{2}$ thin films were prepared in an ion-assisted electron-beam evaporation system assembled by Branchy Vacuum Technology Co., Ltd. (Taoyuan, Taiwan), as described previously [13]. Visible light-responsive $\mathrm{TiO}_{2}-\mathrm{Pt}$ NPs were prepared through a reduction process using chloroplatinic acid and $\mathrm{TiO}_{2} \mathrm{NPs}$ as the platinum precursor and pristine photocatalysts, respectively, also as described previously [11]. Next, platinum-containing nanostructured $\mathrm{TiO}_{2}$ particles $(\mathrm{TiO}-\mathrm{Pt})$ were prepared through a photoreduction process using chloroplatinic acid $\left(\mathrm{H}_{2} \mathrm{PtCl}_{6}\right)$ and commercial $\mathrm{TiO}_{2}$ nanoparticles (ST01; Ishihara, Singapore, Singapore) as the platinum precursor and pristine photocatalysts, respectively. $\mathrm{TiO}_{2}$-Pt was prepared by mixing $38 \mathrm{mmol}$ of nonporous $\mathrm{TiO}_{2}(\mathrm{ST} 01)$ and $0.19 \mathrm{mmol}$ of $\mathrm{H}_{2} \mathrm{PtCl}_{6} \cdot 6 \mathrm{H}_{2} \mathrm{O}$ in $100 \mathrm{~mL}$ of doubly-distilled water. The $\mathrm{TiO}_{2}$ suspension and $\mathrm{H}_{2} \mathrm{PtCl}_{6}$ solution were mixed well using an ultrasonic treatment for $30 \mathrm{~min}$, and the $\mathrm{pH}$ value was adjusted to 6 with $0.1 \mathrm{M}$ of $\mathrm{NaOH}$ solution using a pH meter (Model 6171, Jenco Instruments, San Diego, CA, USA). Subsequently, a nitrogen stream $(100 \mathrm{~mL} / \mathrm{min})$ was continuously purged into the reaction chamber to remove oxygen from the solution. The solution was then irradiated with four UV lamps (TUV 10W/G10 T8; Philips Taiwan, Taipei, Taiwan) at an intensity of $1.7 \mathrm{~mW} / \mathrm{cm}^{2}$ for $4 \mathrm{~h}$. Platinum ions were reduced to platinum metallic nanoparticles by the photo-generated electrons of $\mathrm{TiO}_{2}$ and then deposited on the surfaces of $\mathrm{TiO}_{2}$. Next, the $\mathrm{TiO}_{2}-\mathrm{Pt}$ particles with a Pt/Ti molar ratio of $0.5 \%$ were obtained though centrifugation at $1 \times 10^{4} \mathrm{rpm}$, washed with deionized water and finally dried at $373 \mathrm{~K}$ for $3 \mathrm{~h}$. A diffuse-reflectance scanning spectrophotometer (UV-2450; Shimadzu, Kyoto, Japan) was used to obtain the UV-visible absorption spectra of the NPs, which were shown in our previous work [16]. The average particle size and morphology were determined through transmission electron microscopy (Tecnai G2 F20 TEM, FEI, Hillsboro, OR, USA), and the crystal phase of the photocatalyst was identified through X-ray diffractometry with $\mathrm{CuK} \alpha$ radiation $(\lambda=0.154 \mathrm{~nm}, \mathrm{D} / \mathrm{Max} \mathrm{RC}$; Rigaku, Tokyo, Japan). Finally, the material compositions were determined using $X$-ray photoelectron spectroscopy (SSI-M probe XPS system; Perkin Elmer, Waltham, MA, USA), as described previously [11]. The emission spectra of irradiated UV light and visible light used in this study were analyzed and illustrated (Figure S3).

\subsection{Bacterial Strains and Culture}

E. coli XL1-blue (genotype: recA1 endA1 gyrA96 thi-1 hsdR17 supE44 relA1 lac [F' proAB lacIq Z $\Delta$ M15 Tn10 (Tet')]) was maintained and grown in Luria-Bertani (LB) broth or agar (MDBio, Inc. Taipei, Taiwan) at $37^{\circ} \mathrm{C}$ using a standard laboratory E. coli culture method, as described previously $[9,13,56]$. The bacteria were stored in $50 \%$ glycerol $(v / v)$ in a culture medium at $-80{ }^{\circ} \mathrm{C}$ before use. Later, to reactivate the bacteria from the frozen stocks, $25-\mu \mathrm{L}$ bacterial stock solutions were transferred to a test tube containing $5 \mathrm{~mL}$ of freshly prepared culture medium and then incubated at $37^{\circ} \mathrm{C}$ under agitation overnight (16-18 h).

\subsection{Plasmids}

Glutathione S-transferase expression plasmid pGEX-2KS [28,30-38], His-tag expression plasmid pET16 (Merck, Novagen, Darmstadt, Germany) $[29,57,58]$ and cloning vector pBlueScript II SK ${ }^{+}$ (Takara, Clontech Laboratories, Shiga, Japan) [59] were used in this study. All of the plasmid DNA was isolated using plasmid purification kits, according to the manufacturers' instructions (Qiagen Taiwan, Taipei, Taiwan). The quantity and quality of DNA were determined by measuring the plasmid absorbance at $260 \mathrm{~nm}$ and the absorbance ratio at 260/280 nm, respectively, on a UV-visible spectrophotometer (Hitachi Taiwan, Taipei, Taiwan) [15,60] and Nanodrop spectrophotometer (Thermo Scientific, Wilmington, DE, USA) [61,62]. All relevant standard molecular biological methods were used to amplify, purify and store the plasmids [56]. 


\subsection{Photocatalytic Reaction of Plasmid DNA}

First, plasmid DNA was dissolved and adjusted on a $2 \mu \mathrm{g} / 10 \mu \mathrm{L}$ of Tris- $\mathrm{HCl}(\mathrm{pH} 7.5)$ buffer. In the UV light-responsive photocatalysis experiments, the DNA-containing solution ( $1 \mu \mathrm{g}$ DNA) was placed on a $\mathrm{TiO}_{2}$ thin film and irradiated with UV light at $0.5 \mathrm{~mW} / \mathrm{cm}^{2}$ (UV lamp, Sankyo Denki, Kanagawa, Japan) for $10 \mathrm{~min}$. Subsequently, in the visible light-responsive $\mathrm{TiO}_{2}-\mathrm{Pt} \mathrm{NP}$-mediated photocatalysis experiments, $0.2 \mu \mathrm{g}$ of plasmid DNA were added to $100 \mu \mathrm{L}$ of $0.5 \mathrm{mg} / \mathrm{mL} \mathrm{TiO}{ }_{2}-\mathrm{Pt}$ solution in 24-well plates and then placed under a visible light lamp (Classictone, incandescent lamp, 60W; Philips, Taiwan) with an intensity of $10^{4} \mathrm{lux}\left(30 \mathrm{~mW} / \mathrm{cm}^{2}\right)$. UV light-responsive $\mathrm{P}_{2} 5 \mathrm{TiO}_{2} \mathrm{NPs}$ (Evonik, Essen, Germany) were used for comparison. The crystal structure of the $\mathrm{P}^{25} \mathrm{TiO}_{2}$ was a mixture of $75 \%$ anatase and $25 \%$ rutile $\mathrm{TiO}_{2}$; the purity was at least $99.5 \% \mathrm{TiO}_{2}$, and the primary particle size was $21 \mathrm{~nm}$, with a specific surface area of $50 \pm 15 \mathrm{~m}^{2} / \mathrm{g}$. Notably, the $\mathrm{P} 25 \mathrm{TiO}_{2} \mathrm{NPs}_{\mathrm{s}}$ have been used in several other antibacterial studies $[2,9,12,63]$. The DNA samples (i.e., photocatalyst NPs and plasmid-containing 24-well plates) of the "dark" groups in the photocatalysis experiments were covered with aluminum foil to prevent photocatalysis. Finally, competent $E$. coli cells were transformed with the photocatalyzed DNA, and the transformants were counted $18 \mathrm{~h}$ after plating on LB agar.

\subsection{Blue-White Screen and Mutation Site Analysis}

The blue-white screen was originally developed as a screening technique for rapid and convenient recombinant bacteria detection in vector-based molecular cloning experiments [56]. The method is based on the principle of $\alpha$-complementation of the $\beta$-galactosidase gene lacZ; therefore, the plasmid should contain $l a c Z \alpha$ (i.e., an encoding lac $Z \alpha$-peptide, such as pBlueScript II SK ${ }^{+}$), whereas the E. coli strain (e.g., E. coli XL1-blue) must contain mutated lacZ with a deleted sequence (e.g., lacZ $\Delta M 15$ ). Here, the plasmid was transformed into competent host $E$. coli XL1-blue cells [30], which were then plated on LB agar plates containing $100 \mu \mathrm{g} / \mathrm{mL}$ ampicillin, $50 \mathrm{~g} / \mathrm{mL}$ X-gal and $0.1 \mathrm{mM}$ isopropyl $\beta$-D-1-thiogalactopyranoside (Sigma-Aldrich, St. Louis, MO, USA) [30]. These plates were then incubated overnight at $37^{\circ} \mathrm{C}$; after the colonies grew to an appropriate size, the plates were transferred to a $4{ }^{\circ} \mathrm{C}$ freezer. The $E$. coli cells transformed with mutant lacZ $\alpha$-containing plasmid developed white colonies, whereas the cells transformed with functional lac $\mathrm{Z} \alpha$ produced blue colonies. The white colonies of E. coli transformed with photocatalyzed plasmid DNA (pBlueScript II SK ${ }^{+}$) were then collected, amplified and stocked, and the plasmid DNA was further purified from these E. coli clones. Next, the lacZ $\alpha$ region was sequenced using the primers for the T7 promoter $5^{\prime}$-TAA TAC GAC TCA CTA TAG GG-3' (reverse) and T3 promoter 5'-GCA ATT AAC CCT CAC TAA AGG-3' (forward) located at the flanking sites of the lac $\mathrm{Z} \alpha$ region. The primer synthesis and DNA sequencing were performed by PURIGO Biotechnology (Taipei, Taiwan) [64,65], [and the DNA sequence alignment was performed using the CLC sequence viewer 6.0.2 (CLC Bio, Qiagen, Taiwan, Taipei, Taiwan). Finally, the translation of DNA sequences into protein sequences was performed using a free online system [66].

\subsection{Statistical Analysis}

The means, standard deviations and statistics for the quantifiable data were calculated using Microsoft Office Excel 2003, SigmaPlot 10 and SPSS 19. The significance of the data was examined using one-way ANOVA, followed by post hoc Bonferroni correction. The probability of a type 1 error $(\alpha=0.05)$ was identified as the threshold of statistical significance.

\section{Conclusions}

In the present study, through plasmid transformation and $\beta$-galactosidase $\alpha$-complementation analyses, we determined that visible light-responsive $\mathrm{TiO}_{2}-\mathrm{Pt}$ NPs-mediated photocatalysis considerably reduced the number of E. coli transformants, suggesting that the photocatalytic reactions cause DNA damage. The DNA sequencing analyses further indicated that such DNA damage comprises three mutation types, namely nucleotide insertion, deletion and substitution. This is 
a pioneer study that has identified the types of mutations occurring after photocatalysis by $\mathrm{TiO}_{2}-\mathrm{VLRPs}$ and which may facilitate the development and appropriate usage of new-generation $\mathrm{TiO}_{2} \mathrm{NPs}$ for biomedical applications.

Supplementary Materials: The following are available online at http://www.mdpi.com/2079-4991/7/1/2/s1.

Acknowledgments: We are grateful to Ming F. Tam (Institute of Molecular Biology, Academia Sinica) for his kindly provided plasmid pGEX-2KS decades ago; even before the pGEX-series GST expression plasmids were commercially available from the Pharmacia (now available from GE Healthcare Life Sciences). This work was supported by the Ministry of Science and Technology of Taiwan R.O.C. under Grant No. 95-2314-B-320-009-MY3 and 102-2221-E-259-005-MY3 and the Ministry of Economic Affairs of Taiwan R.O.C. under Grant No. 98-EC-17-A-19-S2-0111.

Author Contributions: Der-Shan Sun and Hsin-Hou Chang conceived of and designed the experiments. Yao-Hsuan Tseng and Wen-Shiang Wu performed the experiments. Hsin-Hou Chang analyzed the data. Yao-Hsuan Tseng and Ming-Show Wong contributed reagents/materials/analysis tools. Hsin-Hou Chang wrote the paper.

Conflicts of Interest: The authors declare no conflict of interest. The founding sponsors had no role in the design of the study; in the collection, analyses or interpretation of data; in the writing of the manuscript; nor in the decision to publish the results.

\section{Abbreviations}

The following abbreviations are used in this manuscript:

$\begin{array}{ll}\mathrm{TiO}_{2} & \text { titanium dioxide } \\ \mathrm{TiO}_{2}-\mathrm{Pt} & \text { platinum-containing } \mathrm{TiO}_{2} \\ \mathrm{VLRP} & \text { visible light-driven photocatalyst } \\ \mathrm{NPs} & \text { nanoparticles } \\ \mathrm{UV} & \text { ultraviolet } \\ \mathrm{ROS} & \text { reactive oxygen species } \\ \cdot \mathrm{OH} & \text { hydroxyl radicals } \\ \mathrm{O}_{2}^{-} & \text {superoxide anions } \\ \mathrm{MCS} & \text { multiple cloning site }\end{array}$

\section{References}

1. Arias, C.A.; Murray, B.E. Antibiotic-resistant bugs in the 21st century-A clinical super-challenge. N. Engl. J. Med. 2009, 360, 439-443. [CrossRef] [PubMed]

2. Liou, J.W.; Chang, H.H. Bactericidal effects and mechanisms of visible light-responsive titanium dioxide photocatalysts on pathogenic bacteria. Arch. Immunol. Ther. Exp. 2012, 60, 267-275. [CrossRef] [PubMed]

3. Tsai, T.M.; Chang, H.H.; Chang, K.C.; Liu, L.Y.; Tseng, C.C. A comparative study of the bactericidal effect of photocatalytic oxidation by $\mathrm{TiO}_{2}$ on antibiotic-resistant and antibiotic-sensitive bacteria. J. Chem. Technol. Biotechnol. 2010, 85, 1642-1653. [CrossRef]

4. Tseng, C.C.; Tsai, Y.H.; Hu, A.; Liou, J.W.; Chang, K.C.; Chang, H.H. Altered susceptibility to the bactericidal effect of photocatalytic oxidation by $\mathrm{TiO}_{2}$ is related to colistin resistance development in acinetobacter baumannii. Appl. Microbiol. Biotechnol. 2016, 100, 8549-8561. [CrossRef] [PubMed]

5. Linsebigler, A.L.; Lu, G.; Yates, J.T. Photocatalysis on $\mathrm{TiO}_{2}$ surfaces: Principles, mechanisms, and selected results. Chem. Rev. 1995, 95, 735-758. [CrossRef]

6. Sliney, D.H. Optical radiation safety of medical light sources. Phys. Med. Biol. 1997, 42, 981-996. [CrossRef] [PubMed]

7. Wu, M.S.; Sun, D.S.; Lin, Y.C.; Cheng, C.L.; Hung, S.C.; Chen, P.K.; Yang, J.H.; Chang, H.H. Nanodiamonds protect skin from ultraviolet B-induced damage in mice. J. Nanobiotechnol. 2015, 13, 35. [CrossRef] [PubMed]

8. Chang, W.K.; Sun, D.S.; Chan, H.; Huang, P.T.; Wu, W.S.; Lin, C.H.; Tseng, Y.H.; Cheng, Y.H.; Tseng, C.C.; Chang, H.H. Visible light responsive core-shell structured $\mathrm{In}_{2} \mathrm{O}_{3} @ \mathrm{CaIn} 2 \mathrm{O}_{4}$ photocatalyst with superior bactericidal property and biocompatibility. Nanomed. Nanotechnol. Biol. Med. 2012, 8, 609-617. [CrossRef] [PubMed]

9. Cheng, C.L.; Sun, D.S.; Chu, W.C.; Tseng, Y.H.; Ho, H.C.; Wang, J.B.; Chung, P.H.; Chen, J.H.; Tsai, P.J.; Lin, N.T.; et al. The effects of the bacterial interaction with visible-light responsive titania photocatalyst on the bactericidal performance. J. Biomed. Sci. 2009, 16, 7. [CrossRef] [PubMed] 
10. Liou, J.W.; Gu, M.H.; Chen, Y.K.; Chen, W.Y.; Chen, Y.C.; Tseng, Y.H.; Hung, Y.J.; Chang, H.H. Visible light responsive photocatalyst induces progressive and apical-terminus preferential damages on Escherichia coli surfaces. PLoS ONE 2011, 6, e19982. [CrossRef] [PubMed]

11. Tseng, Y.H.; Sun, D.S.; Wu, W.S.; Chan, H.; Syue, M.S.; Ho, H.C.; Chang, H.H. Antibacterial performance of nanoscaled visible-light responsive platinum-containing titania photocatalyst in vitro and in vivo. Biochim. Biophys. Acta 2013, 1830, 3787-3795. [CrossRef] [PubMed]

12. Wong, M.S.; Chen, C.W.; Hsieh, C.C.; Hung, S.C.; Sun, D.S.; Chang, H.H. Antibacterial property of AG nanoparticle-impregnated N-doped titania films under visible light. Sci. Rep. 2015, 5, 11978. [CrossRef] [PubMed]

13. Wong, M.S.; Chu, W.C.; Sun, D.S.; Huang, H.S.; Chen, J.H.; Tsai, P.J.; Lin, N.T.; Yu, M.S.; Hsu, S.F.; Wang, S.L.; et al. Visible-light-induced bactericidal activity of a Nitrogen-Doped titanium photocatalyst against human pathogens. Appl. Environ. Microbiol. 2006, 72, 6111-6116. [CrossRef] [PubMed]

14. Wong, M.S.; Sun, D.S.; Chang, H.H. Bactericidal performance of visible-light responsive titania photocatalyst with silver nanostructures. PLoS ONE 2010, 5, e10394. [CrossRef] [PubMed]

15. Kau, J.H.; Sun, D.S.; Huang, H.H.; Wong, M.S.; Lin, H.C.; Chang, H.H. Role of visible light-activated photocatalyst on the reduction of anthrax spore-induced mortality in mice. PLoS ONE 2009, 4, e4167. [CrossRef] [PubMed]

16. Chen, Y.L.; Chen, Y.S.; Chan, H.; Tseng, Y.H.; Yang, S.R.; Tsai, H.Y.; Liu, H.Y.; Sun, D.S.; Chang, H.H. The use of nanoscale visible light-responsive photocatalyst $\mathrm{TiO}_{2}-\mathrm{Pt}$ for the elimination of soil-borne pathogens. PLOS ONE 2012, 7, e31212.

17. Xie, J.; Pan, X.; Wang, M.; Yao, L.; Liang, X.; Ma, J.; Fei, Y.; Wang, P.N.; Mi, L. Targeting and photodynamic killing of cancer cell by Nitrogen-Doped titanium dioxide coupled with folic acid. Nanomaterials 2016, 6, 113. [CrossRef]

18. Humayun, M.; Li, Z.; Sun, L.; Zhang, X.; Raziq, F.; Zada, A.; Qu, Y.; Jing, L. Coupling of nanocrystalline anatase $\mathrm{TiO}_{2}$ to porous nanosized $\mathrm{LaFeO}_{3}$ for efficient visible-light photocatalytic degradation of pollutants. Nanomaterials 2016, 6, 22. [CrossRef]

19. Sun, D.S.; Kau, J.H.; Huang, H.H.; Tseng, Y.H.; Wu, W.S.; Chang, H.H. Antibacterial properties of visible-light-responsive carbon-containing titanium dioxide photocatalytic nanoparticles against anthrax. Nanomaterials 2016, 6, 237. [CrossRef]

20. Fujishima, A.; Honda, K. Electrochemical photolysis of water at a semiconductor electrode. Nature 1972, 238, 37-38. [CrossRef] [PubMed]

21. Legrini, O.; Oliveros, E.; Braun, A.M. Photochemical processes for water treatment. Chem. Rev. 1993, 93, 671-698. [CrossRef]

22. Lu, Z.X.; Zhang, Z.L.; Zhang, M.X.; Xie, H.Y.; Tian, Z.Q.; Chen, P.; Huang, H.; Pang, D.W. Core/shell quantum-dot-photosensitized nano- $\mathrm{TiO}_{2}$ films: Fabrication and application to the damage of cells and DNA. J. Phys. Chem. B 2005, 109, 22663-22666. [CrossRef] [PubMed]

23. Shen, X.C.; Zhang, Z.L.; Zhou, B.; Peng, J.; Xie, M.; Zhang, M.; Pang, D.W. Visible light-induced plasmid DNA damage catalyzed by a CdSe/ZnS-photosensitized nano- $\mathrm{TiO}_{2}$ film. Environ. Sci. Technol. 2008, 42, 5049-5054. [CrossRef] [PubMed]

24. Markovitsi, D. UV-induced DNA damage: The role of electronic excited states. Photochem. Photobiol. 2016, 92, 45-51. [CrossRef] [PubMed]

25. Sugasawa, K. Molecular mechanisms of DNA damage recognition for mammalian nucleotide excision repair. DNA Repair 2016, 44, 110-117. [CrossRef] [PubMed]

26. Fujishima, A.; Rao, T.N.; Tryk, D.A. Titanium dioxide photocatalysis. J. Photochem. Photobiol. C 2000, 1, 1-21. [CrossRef]

27. Bruskov, V.I.; Malakhova, L.V.; Masalimov, Z.K.; Chernikov, A.V. Heat-induced formation of reactive oxygen species and 8-oxoguanine, a biomarker of damage to DNA. Nucleic Acids Res. 2002, 30, 1354-1363. [CrossRef] [PubMed]

28. Chang, H.H.; Hu, S.T.; Huang, T.F.; Chen, S.H.; Lee, Y.H.; Lo, S.J. Rhodostomin, an RGD-containing peptide expressed from a synthetic gene in Escherichia coli, facilitates the attachment of human hepatoma cells. Biochem. Biophys. Res. Commun. 1993, 190, 242-249. [CrossRef] [PubMed] 
29. Chang, H.H.; Shyu, H.F.; Wang, Y.M.; Sun, D.S.; Shyu, R.H.; Tang, S.S.; Huang, Y.S. Facilitation of cell adhesion by immobilized dengue viral nonstructural protein 1 (NS1): Arginine-glycine-aspartic acid structural mimicry within the dengue viral ns1 antigen. J. Infect. Dis. 2002, 186, 743-751. [CrossRef] [PubMed]

30. Chang, H.H.; Shih, K.N.; Lo, S.J. Receptor-mediated endocytosis as a selection force to enrich bacteria expressing rhodostomin on their surface. J. Biomed. Sci. 2000, 7, 42-50. [CrossRef] [PubMed]

31. Chang, H.J.; Sheu, S.Y.; Lo, S.J. Expression of foreign antigens on the surface of Escherichia coli by fusion to the outer membrane protein trat. J. Biomed. Sci. 1999, 6, 64-70. [CrossRef] [PubMed]

32. Chang, H.H.; Chen, P.K.; Lin, G.L.; Wang, C.J.; Liao, C.H.; Hsiao, Y.C.; Dong, J.H.; Sun, D.S. Cell adhesion as a novel approach to determining the cellular binding motif on the severe acute respiratory syndrome coronavirus spike protein. J. Virol. Methods 2014, 201, 1-6. [CrossRef] [PubMed]

33. Chang, C.P.; Chang, J.C.; Chang, H.H.; Tsai, W.J.; Lo, S.J. Positional importance of Pro53 adjacent to the Arg49-Gly50-Asp51 sequence of rhodostomin in binding to integrin $\alpha \mathrm{IIb} \beta 3$. Biochem. J. 2001, 357, 57-64. [CrossRef] [PubMed]

34. Chang, H.H.; Chang, C.P.; Chang, J.C.; Dung, S.Z.; Lo, S.J. Application of recombinant rhodostomin in studying cell adhesion. J. Biomed. Sci. 1997, 4, 235-243. [CrossRef] [PubMed]

35. Chang, H.H.; Lin, C.H.; Lo, S.J. Recombinant rhodostomin substrates induce transformation and active calcium oscillation in human platelets. Exp. Cell Res. 1999, 250, 387-400. [CrossRef] [PubMed]

36. Chang, H.H.; Lo, S.J. Full-spreading platelets induced by the recombinant rhodostomin are via binding to integrins and correlated with fak phosphorylation. Toxicon 1998, 36, 1087-1099. [CrossRef]

37. Chang, H.H.; Tsai, W.J.; Lo, S.J. Glutathione S-transferase-rhodostomin fusion protein inhibits platelet aggregation and induces platelet shape change. Toxicon 1997, 35, 195-204. [CrossRef]

38. Chang, H.; Lo, S.J. Modification with a phosphorylation tag of PKA in the trat-based display vector of Escherichia coli. J. Biotechnol. 2000, 78, 115-122. [CrossRef]

39. Ahmad, J.; Dwivedi, S.; Alarifi, S.; Al-Khedhairy, A.A.; Musarrat, J. Use of $\beta$-galactosidase (lacZ) gene alpha-complementation as a novel approach for assessment of titanium oxide nanoparticles induced mutagenesis. Mutat. Res. 2012, 747, 246-252. [CrossRef] [PubMed]

40. Halliwell, B.; Aruoma, O.I. DNA damage by oxygen-derived species. Its mechanism and measurement in mammalian systems. FEBS Lett. 1991, 281, 9-19. [CrossRef]

41. Wiseman, H.; Halliwell, B. Damage to DNA by reactive oxygen and nitrogen species: Role in inflammatory disease and progression to cancer. Biochem. J. 1996, 313, 17-29. [CrossRef] [PubMed]

42. Waris, G.; Ahsan, H. Reactive oxygen species: Role in the development of cancer and various chronic conditions. J. Carcinog. 2006, 5, 14. [CrossRef] [PubMed]

43. Berquist, B.R.; Wilson, D.M., III. Pathways for repairing and tolerating the spectrum of oxidative DNA lesions. Cancer Lett. 2012, 327, 61-72. [CrossRef] [PubMed]

44. Greinert, R.; Volkmer, B.; Henning, S.; Breitbart, E.W.; Greulich, K.O.; Cardoso, M.C.; Rapp, A. UVA-induced DNA double-strand breaks result from the repair of clustered oxidative DNA damages. Nucleic Acids Res. 2012, 40, 10263-10273. [CrossRef] [PubMed]

45. Jena, N.R. DNA damage by reactive species: Mechanisms, mutation and repair. J. Biosci. 2012, 37, 503-517. [CrossRef] [PubMed]

46. Sinha, R.P.; Hader, D.P. UV-induced DNA damage and repair: A review. Photochem. Photobiol. Sci. 2002, 1, 225-236. [CrossRef] [PubMed]

47. Seeley, T.W.; Grossman, L. The role of Escherichia coli UvrB in nucleotide excision repair. J. Biol. Chem. 1990, 265, 7158-7165. [PubMed]

48. Liu, B.; Xue, Q.; Tang, Y.; Cao, J.; Guengerich, F.P.; Zhang, H. Mechanisms of mutagenesis: DNA replication in the presence of DNA damage. Mutat. Res. Rev. Mutat. Res. 2016, 768, 53-67. [CrossRef] [PubMed]

49. Li, S.; Xiong, X.; Li, W. The breakage and damage of plasmid DNA photocatalized by $\mathrm{TiO}_{2} /$ carbon nanotube composites. Surf. Interface Anal. 2012, 44, 84-88. [CrossRef]

50. Van Gent, D.C.; Hoeijmakers, J.H.; Kanaar, R. Chromosomal stability and the DNA double-stranded break connection. Nat. Rev. Genet. 2001, 2, 196-206. [CrossRef] [PubMed]

51. Lieber, M.R. The mechanism of double-strand DNA break repair by the nonhomologous DNA end-joining pathway. Annu. Rev. Biochem. 2010, 79, 181-211. [CrossRef] [PubMed]

52. Rastogi, R.P.; Richa, K.; Kumar, A.; Tyagi, M.B.; Sinha, R.P. Molecular mechanisms of ultraviolet radiation-induced DNA damage and repair. J. Nucleic Acids 2010, 2010, 592980. [CrossRef] [PubMed] 
53. Choi, J.H.; Besaratinia, A.; Lee, D.H.; Lee, C.S.; Pfeifer, G.P. The role of DNA polymerase I in UV mutational spectra. Mutat. Res. 2006, 599, 58-65. [CrossRef] [PubMed]

54. Zhou, A.; Kang, T.M.; Yuan, J.; Beppler, C.; Nguyen, C.; Mao, Z.; Nguyen, M.Q.; Yeh, P.; Miller, J.H. Synergistic interactions of vancomycin with different antibiotics against Escherichia coli: Trimethoprim and nitrofurantoin display strong synergies with vancomycin against wild-type E. Coli. Antimicrob. Agents Chemother. 2015, 59, 276-281. [CrossRef] [PubMed]

55. Kohanski, M.A.; Dwyer, D.J.; Collins, J.J. How antibiotics kill bacteria: From targets to networks. Nat. Rev. Microbiol. 2010, 8, 423-435. [CrossRef] [PubMed]

56. Sambrook, J.; Fritsch, E.F.; Maniatis, T. Molecular Cloning: A Laboratory Manual, 2nd ed.; Cold Spring Harbor Laboratory Press: Cold Spring Harbor, Woodbury, NY, USA, 1989.

57. Lien, T.S.; Sun, D.S.; Chang, C.M.; Wu, C.Y.; Dai, M.S.; Chan, H.; Wu, W.S.; Su, S.H.; Lin, Y.Y.; Chang, H.H. Dengue virus and antiplatelet autoantibodies synergistically induce haemorrhage through Nlrp3-inflammasome and Fc $\gamma$ RIII. Thromb. Haemost. 2015, 113, 1060-1070. [CrossRef] [PubMed]

58. Sun, D.S.; Chang, Y.C.; Lien, T.S.; King, C.C.; Shih, Y.L.; Huang, H.S.; Wang, T.Y.; Li, C.R.; Lee, C.C.; Hsu, P.N.; et al. Endothelial cell sensitization by death receptor fractions of an anti-dengue nonstructural protein 1 antibody induced plasma leakage, coagulopathy, and mortality in mice. J. Immunol. 2015, 195, 2743-2753. [CrossRef] [PubMed]

59. Lee, M.W.; Chang, A.C.; Sun, D.S.; Hsu, C.Y.; Chang, N.C. Restricted expression of LUZP in neural lineage cells: A study in embryonic stem cells. J. Biomed. Sci. 2001, 8, 504-511. [CrossRef] [PubMed]

60. Sun, D.S.; Lee, P.C.; Kau, J.H.; Shih, Y.L.; Huang, H.H.; Li, C.R.; Lee, C.C.; Wu, Y.P.; Chen, K.C.; Chang, H.H. Acquired coagulant factor VIII deficiency induced by bacillus anthracis lethal toxin in mice. Virulence 2015, 6, 466-475. [CrossRef] [PubMed]

61. Jagessar, S.A.; Holtman, I.R.; Hofman, S.; Morandi, E.; Heijmans, N.; Laman, J.D.; Gran, B.; Faber, B.W.; van Kasteren, S.I.; Eggen, B.J.; et al. Lymphocryptovirus infection of nonhuman primate B cells converts destructive into productive processing of the pathogenic CD8 T cell epitope in myelin oligodendrocyte glycoprotein. J. Immunol. 2016, 197, 1074-1088. [CrossRef] [PubMed]

62. Luhung, I.; Wu, Y.; Ng, C.K.; Miller, D.; Cao, B.; Chang, V.W. Protocol improvements for low concentration DNA-based bioaerosol sampling and analysis. PLoS ONE 2015, 10, e0141158. [CrossRef] [PubMed]

63. Trouiller, B.; Reliene, R.; Westbrook, A.; Solaimani, P.; Schiestl, R.H. Titanium dioxide nanoparticles induce DNA damage and genetic instability in vivo in mice. Cancer Res. 2009, 69, 8784-8789. [CrossRef] [PubMed]

64. Lee, C.F.; Ou, D.S.; Lee, S.B.; Chang, L.H.; Lin, R.K.; Li, Y.S.; Upadhyay, A.K.; Cheng, X.; Wang, Y.C.; Hsu, H.S.; et al. HNaa10p contributes to tumorigenesis by facilitating DNMT1-mediated tumor suppressor gene silencing. J. Clin. Investig. 2010, 120, 2920-2930. [CrossRef] [PubMed]

65. Chiang, C.Y.; Hsieh, C.H.; Chen, M.Y.; Tsai, J.P.; Liu, H.H.; Liu, S.J.; Chong, P.; Leng, C.H.; Chen, H.W. Recombinant lipidated dengue-4 envelope protein domain iii elicits protective immunity. Vaccine 2014, 32, 1346-1353. [CrossRef] [PubMed]

66. Translate DNA and RNA Sequences to Protein Sequences. Available online: http://www.fr33.net/translator.php (accessed on 25 September 2016).

(C) 2016 by the authors; licensee MDPI, Basel, Switzerland. This article is an open access article distributed under the terms and conditions of the Creative Commons Attribution (CC-BY) license (http://creativecommons.org/licenses/by/4.0/). 